Institute for Applied Agroecology Rostock ${ }^{*}$ and Research Institute for the Biology of Farm Animals Dummerstorf, Germany

HEINZ FALKENBERG"), MARTINA LANGHAMMER and ULLA RENNE

\title{
Comparison of biochemical blood traits after long-term selection on high or low locomotory activity in mice
}

\author{
Dedicated to Professor Dr. Dr. h. c. Gerhard von Lengerken on the occasion of his \\ $65^{\text {th }}$ birthday
}

\begin{abstract}
Summary
In a long term experiment laboratory mice were selected for high (line DU-hTP) or low (line DU-ITP) paternal treadmill performance to differentiate the endurance fitness. In generation 54 six enzymes and seven substrates were investigated in the blood plasma of males and females in DU-hTP $(n=104)$ and DU-ITP $(n=141)$. Compared with line DU-ITP in line DU-hTP significantly higher enzyme activities, increased glucose concentration and lower level of triglycerides were found. The components of total cholesterol were divergent between the two lines and positively effected in DU-hTP for higher HDL-cholesterol. Animals with high endurance fitness showed a higher gain in the HDL-cholesterol concentration with increased total cholesterol level in the blood than gain of LDL+VLDL-cholesterol concentration.
\end{abstract}

Key Words: mouse, long-term selection, treadmill performance, selection response, blood traits, substrates, enzymes

\section{Zusammenfassung}

Titel der Arbeit: Auswirkungen der divergenten Selektion nach lokomotorischer Aktivităt auf biochemische Blutmerkmale beim Modelltier Maus

In einem Langzeitexperiment wurden Labormăuse divergent nach hoher (Linie DU-hTP) bzw. niedriger (Linie DU-ITP) paternaler Laufleistung als einem Merkmal fur die Ausdauerbelastbarkeit selektiert. Bei einer gleichen Anzahl mănnlicher und weiblicher Tiere aus der 54. Generation der Linien DU-hTP $(n=104)$ und DU-ITP $(n=$ 141) wurden aus dem Blutplasma sechs Enzyme und sieben Substrate bestimmt. Im Vergleich mit den Tieren aus der Linie DU-ITP wurden bei der Linie DU-hTP signifikant hőhere Enzymaktivităten, eine erhøhte Glukosekonzentration und geringere Triglyceridwerte gefunden. Die Cholesterinuntergruppen unterschieden sich zwischen den Linien, wobei besonders der hohe Anteil von HDL-Cholesterin bei der Linie DU-hTP auffällig war. Bei den Tieren mit hoher Ausdauerfitness zeigte sich mit zunehmender Gesamtcholesterinkonzentration im Blut ein höherer Anstieg von HDL-Cholesterin als von LDL+VLDL-Cholesterin.

Schlusselwörter: Maus, Langzeitselektion, Selektionserfolg, Blutplasmamerkmale, Substrate, Enzyme

\section{Introduction}

Fitness and adaptability are specific features of an animal which are important to fit the organism on the special conditions of its living space. Environmental effects influence the organism which will respond with an reaction to maintain the homeostasis. That will be the basis for survival and health. In farm animals, high quality and quantity in special performance traits are connected with best health and an intact adaptability to environmental conditions. In this connection, conditions and 
standards are investigated which effect health or fitness in an important manner (FLACHOWSKY, 1996). Therefore experiments with laboratory animals play an important role for collecting cognitions to form the environmental conditions of farm animals. An experiment with mice for the evaluation and choice of animals for their physical endurance fitness could make a contribution to above mentioned questions.

In laboratory and farm animals fitness is essential for the development of performance traits. The improvement of features in animal breeding neglected the preservation or development of fitness and adaptability. Selection affects both the direct breeding aim trait and indirect traits as body conformation, quantitative traits or physiological characteristics. Selection for defined traits over a long terminal period could produce animals with several morphological, ethological, physiological and biochemical qualities which differ strongly from the base population. In such investigations laboratory animals often will be used as a model for farm animals or to detect processes in human live.

The subject of this paper is to present the effects of long-term selection for endurance fitness on characteristics in the mice. The results of a divergent selection experiment for high or low endurance performance are considered. While in the high line (DUhTP) males with the best treadmill performance were selected for producing the next generation, the low line (DU-ITP) divergently included those males with the smallest endurance fitness.

The results in Table 2 show the variation of selection response for endurance fitness in dependence of the selection trait. After long term selection treadmill performance increased in line DU-hTP for $28 \%$ and decreased in line DU-1TP for $35 \%$. RENNE et al. (1997) reported about the changes of indirect traits. In the following the results of biochemical traits are compared between the two selection lines and discussed as indirect selection responses.

\section{Material and Methods}

The experiments were carried out in the Mouse Laboratory of the Research Institute of the Biology of Farm Animals in Dummerstorf and based on the outbred strain Fzt:DU, which has been obtained in $1969 / 1970$ by systematic crossbreeding of 4 inbred and 4 outbred lines (SCHÜLER, 1985; RENNE et al., 1984).

Two pure bred lines were splitted from the strain Fzt:DU in 1983. The two lines were selected for high (DU-hTP) or low (DU-1TP) paternal treadmill performance. The experimental design is shown in Table 1. Animals were fed ad libitum with standard feed and water ad libitum.

The endurance fitness was measured by a computer controlled treadmill. The treadmill test is a submaximal test. Mice ran on the treadmill ( $10 \%$ incline) at a rate of about $22.8 \mathrm{~m} / \mathrm{min}$ (start speed: $15 \mathrm{~m} / \mathrm{min}$, final speed: $38 \mathrm{~m} / \mathrm{min}$ ) with a special test program. The test stop depends on remaining the mice on the stimulating equipment of the treadmill (RENNE et al., 1989).

The two mice lines are characterised by their different treadmill performance. The selection response after 54. generation is shown in Table 2. The divergent selection yielded in an improvement of endurance fitness in the line DU-hTP to $128 \%$ and in a reduction in the line DU-ITP of $35 \%$ respectively. 
Arch. Tierz. 43 (2000) 5

Table 1

Experimental design (Versuchsablauf)

mouse lines

DU-hTP DU-ITP

\begin{tabular}{|c|c|c|}
\hline Length of the experiment & 0 to 54 gen & 0 to 54 gen \\
\hline Selection trait & $\begin{array}{l}\text { high treadmill performance } \\
\text { at day } 70\end{array}$ & $\begin{array}{l}\text { low treadmill performance } \\
\text { at day } 70\end{array}$ \\
\hline Selection procedure & \multicolumn{2}{|c|}{ paternal performance test } \\
\hline Litter size standardisation & $4 \sigma, 48$ & $4 \sigma, 48$ \\
\hline $\begin{array}{l}\text { Pairs/generation with mating } \\
\text { ratio } 1 \propto: 1 \% \\
\text { at } 63 \pm 3 \text { days }\end{array}$ & $60-100$ & $60-100$ \\
\hline $\begin{array}{l}\text { Effective population size in } \\
\text { generation } 0\end{array}$ & 200 & 200 \\
\hline $\begin{array}{l}\text { Harmonic mean } \\
\text { for successful pairs (\%) }\end{array}$ & 83.3 & 80.5 \\
\hline Selection quote $(\%)$ & 44.9 & 36.4 \\
\hline
\end{tabular}

Table 2

Selection response for treadmill performance (Selektionserfolg im Merkmal Laufleistung)

\begin{tabular}{llll}
\hline Selection line & Selection trait & Selection response & $\%$ \\
\hline DU-hTP & high treadmill performance & $1719 \mathrm{~m}$ & 128 \\
DU-ITP & low treadmill performance & $-323 \mathrm{~m}$ & 65 \\
\hline
\end{tabular}

For the examination of blood traits 104 mice in line DU-hTP and 141 mice in line DUITP with about the same sex ratio were included.

The blood was collected at slaughtering on day 70 and frozen after centrifugation for getting blood plasma. The analysed characters were determined photometrically by standard methods at $37^{\circ} \mathrm{C}$. A photometer (LP 400) of the firm LANGE, Berlin was used. The list of the tested enzymes and substances is shown in Table 3.

Table 3

Determined metabolic substances in mice blood plasma (Analysierte Stoffwechselsubstanzen im Blutplasma von Mausen)

\begin{tabular}{|c|c|c|}
\hline Traits & Abbreviation & Unit \\
\hline Aspartate aminotransferase & ASAT (AST, GOT) & nkat/l \\
\hline Alanine aminotransferase & $\operatorname{ALAT}(\mathrm{ALT}, \mathrm{GPT})$ & nkat/l \\
\hline Lactate dehydrogenase & LDH & nkat/l \\
\hline Creatine kinase & $\mathrm{CK}$ & nkat/l \\
\hline Alkaline phosphatase & AP & nkat/l \\
\hline$\gamma$-Glutamyl-transpeptidase & $\operatorname{GGTP}(\gamma-\mathrm{GT})$ & nkat/l \\
\hline Total cholesterol & Chol. & $\mathrm{mmol} / \mathrm{l}$ \\
\hline High density lipoproteins cholersterol & HDL-chol. & $\mathrm{mmol} / \mathrm{l}$ \\
\hline $\begin{array}{l}\text { Low density + very low density lipoproteins } \\
\text { cholesterol }\end{array}$ & LDL+VLDL-chol. & $\mathrm{mmol} / \mathrm{l}$ \\
\hline Triglyceride & Trig. & $\mathrm{mmol} / \mathrm{l}$ \\
\hline Glucose & Gluc. & $\mathrm{mmol} / \mathrm{l}$ \\
\hline Lactate & Lac. & $\mathrm{mmol} / \mathrm{l}$ \\
\hline Creatinine & Crea. & $\mu \mathrm{mol} / 1$ \\
\hline
\end{tabular}


Population genetic analysis were carried out using SAS program package. The effects of sex and line were tested with variance analysis. Phenotypic correlation's between the different metabolic blood traits were calculated for the whole data material.

\section{Results}

The levels of enzyme activity of ASAT, ALAT, LDH, CK, GGTP and AP in DU-hTP and DU-1TP are presented in the following Figure 1. In DU-hTP, all the enzyme
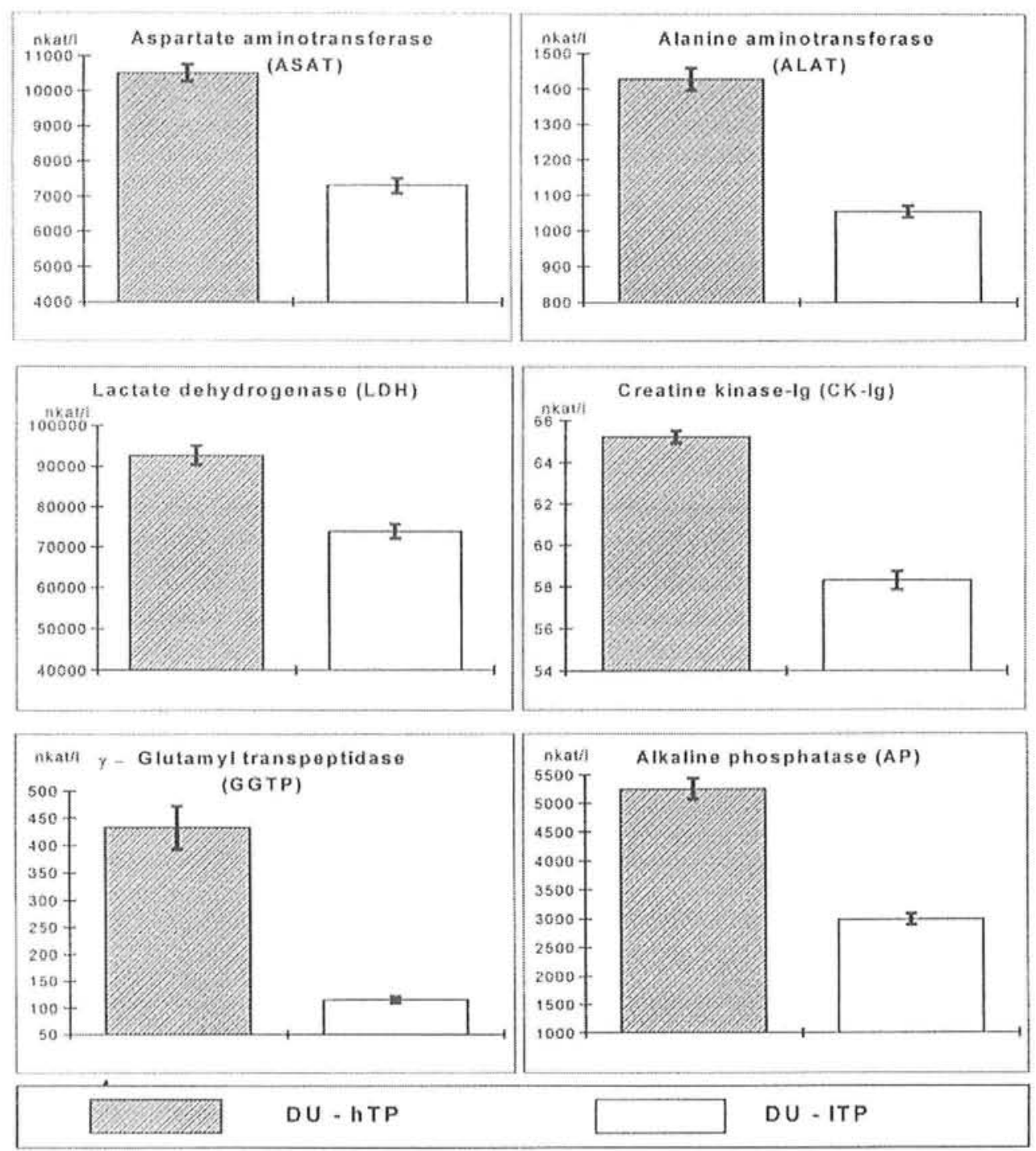

Fig. 1: Enzyme activities in blood of mouse lines DU-hTP and DU-ITP (Enzymaktivităten im Blut der Mauslinien DU-hTP und DU-ITP) 
activities were significantly higher vs. line DU-ITP. In comparison to DU-hTP $(=100 \%)$ the level of enzymes in line DU-ITP reached for CK only $89,4 \%$, for LDH $79,7 \%$, for ASAT 73,7 \%, for ALAT $69,5 \%$, for AP 56,8 \% and for GGTP $26,5 \%$. It is assumed that an active metabolism and the reaction to stress situations are linked with higher enzyme activities in the animals. These results indicate the stronger stress for the animals which were selected for high endurance fitness.

Total cholesterol as an essential component for somatic cells will be transported with the help of special lipoproteins in the blood to all target organs. The subgroups HDLcholesterol and LDL+VLDL-cholesterol are especially important for arteriosclerosis. They are described separately in Figure 2.

As a result of long-term selection, the total cholesterol level differ significantly between the two mouse lines. Whereas the mean cholesterol concentration in blood plasma of the line DU-hTP with high endurance fitness is $4.06 \mathrm{mmol} / \mathrm{l}$, we find higher levels in DU-ITP mice (4.61 mmol/l). But the higher HDL-cholesterol level (1.92 $\mathrm{mmol} / \mathrm{l}$ ) in DU-hTP versus $1.79 \mathrm{mmol} / \mathrm{l}$ in DU-lTP was unexpected. Therefore the LDL+VLDL-cholesterol concentration was reduced in DU-hTP. If the ratio of the two cholesterol subgroups (HDL / LDL+VLDL) is considered, the animals with high endurance fitness in line DU-hTP have better cholesterol values in relation to the physical stage of health.

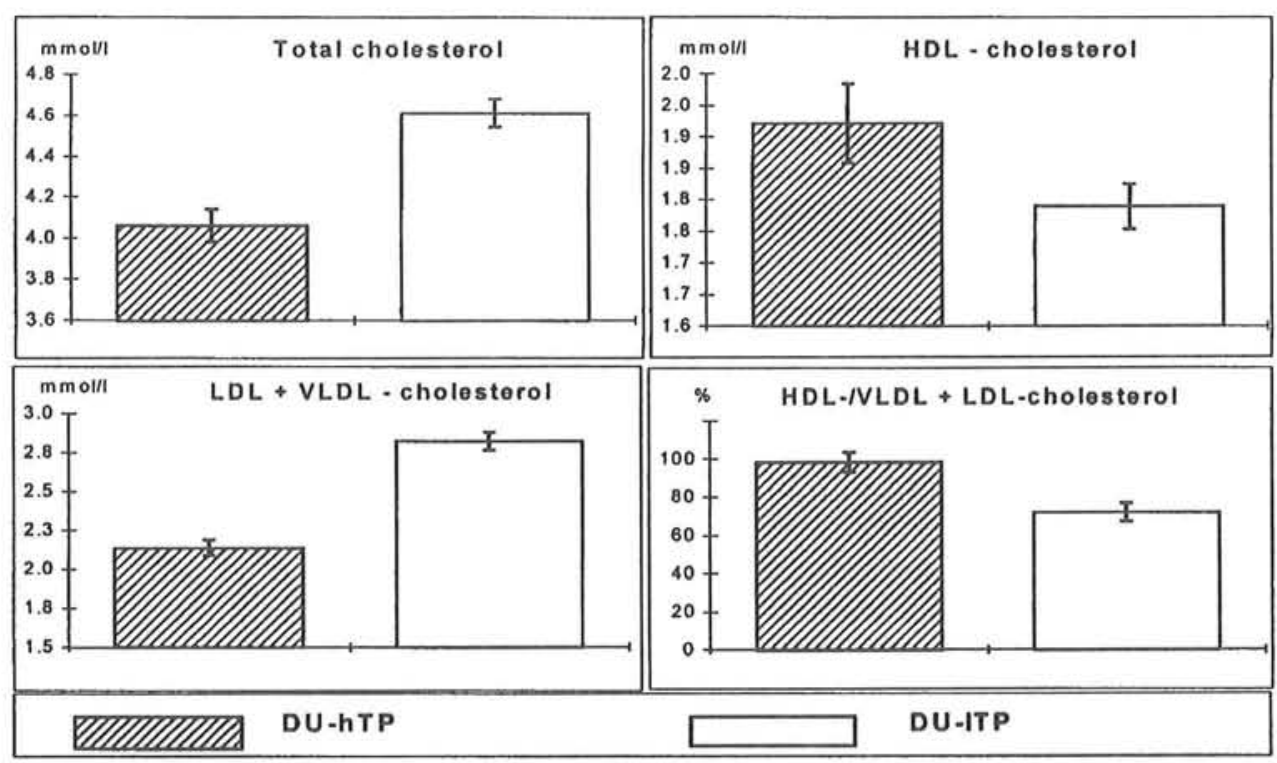

Fig. 2: Cholesterol concentration in blood of mouse lines DU-hTP and DU-ITP (Cholesterinkonzentration im Blut der Mauslinien DU-hTP und DU-ITP)

Figure 3 shows the specific relation between the components of cholesterol. Animals with high endurance fitness showed a higher gain in the HDL-cholesterol concentration with increased total cholesterol level in the blood than gain of LDL+VLDL-cholesterol concentration. 


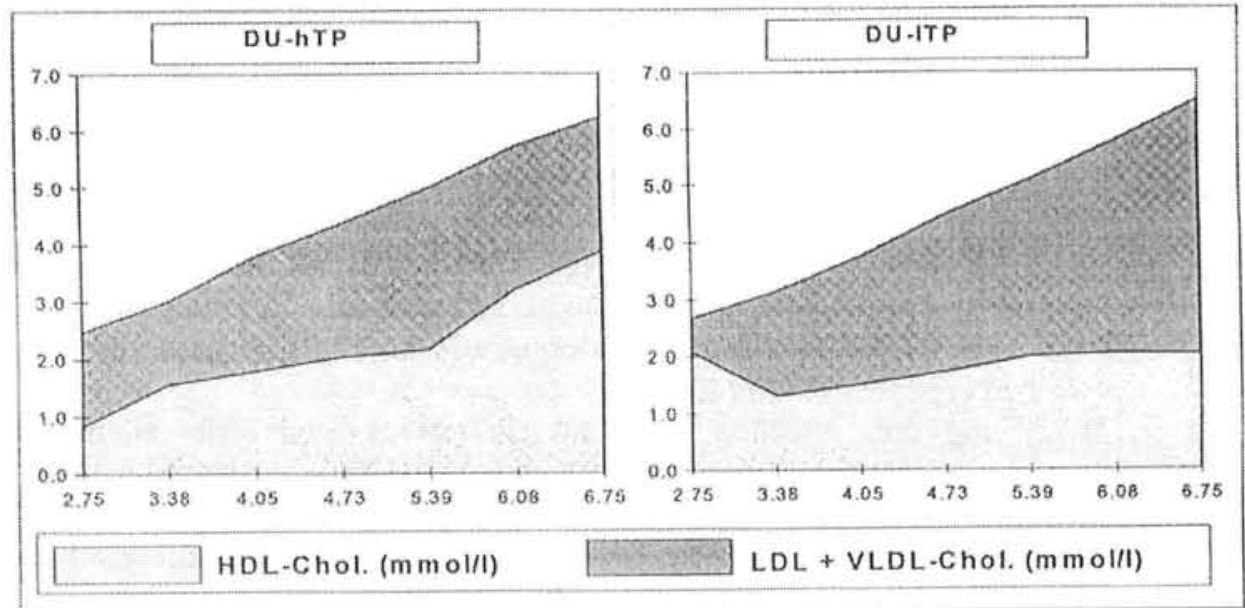

Fig. 3: Variation of cholesterol metabolites in mouse lines DU-hTP and DU-ITP (Veränderungen der Cholesterinuntergruppen bei den Mauslinien DU-hTP und DU-ITP)

Against that in line DU-ITP an increased total cholesterol concentration was connected with especially high LDL+VLDL-cholesterol concentrations and contemporaneously constant HDL- cholesterol.

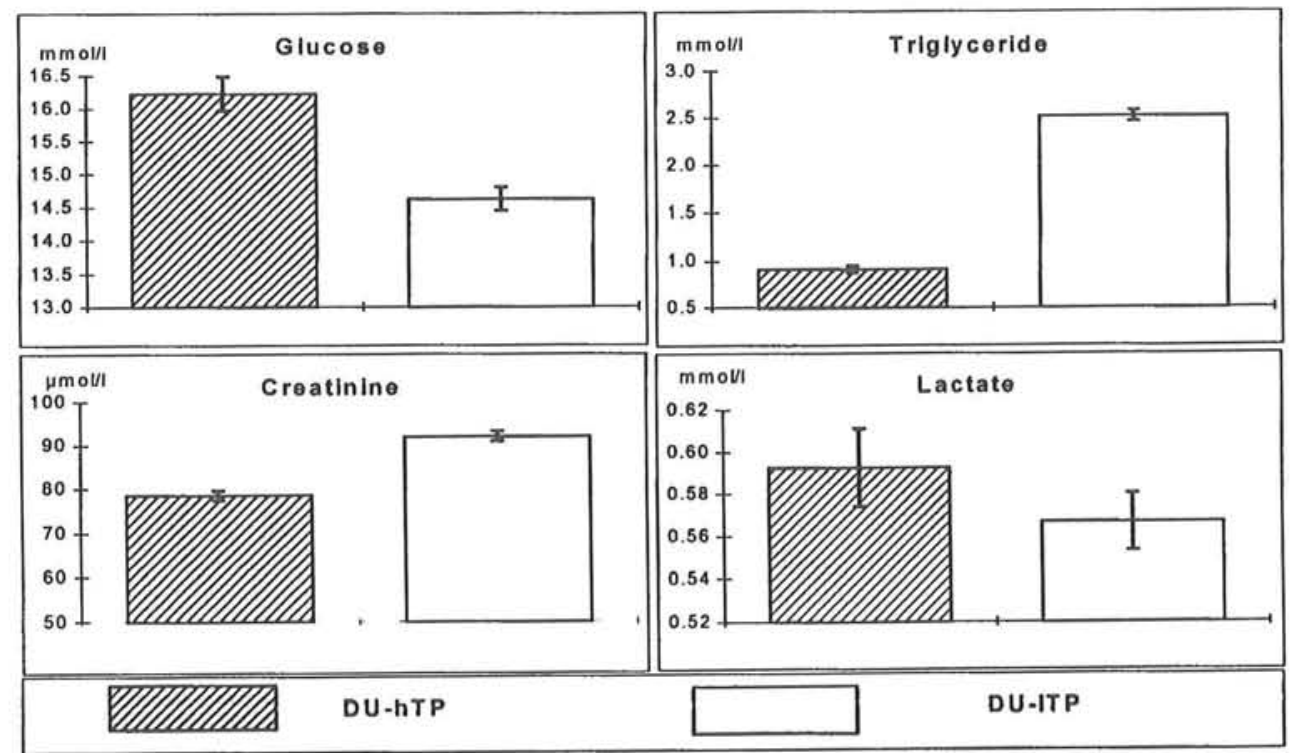

Fig. 4: Substrates in blood of mouse lines DU-hTP and DU-ITP (Substrate im Blut der Mauslinien DU-hTP und DU-ITP)

The relation between HDL- and LDL+VLDL-cholesterol can also be expressed with the help of the phenotypical correlation coefficient $\left(r_{p}\right)$ which are shown in Table 4. 
Table 4

Phenotypic correlation coefficient $\left(\mathrm{r}_{\mathrm{p}}\right)$ between total cholesterol and its components (Phänotypischer Korrelationskoeffizient $\left(r_{p}\right)$ zwischen Gesamt-Cholesterin und seinen Untergruppen)

\begin{tabular}{lll} 
& Chol. : HDL-Chol. & Chol. : LDL+VLDL-Chol. \\
& $\mathrm{r}_{\mathrm{p}}$ & $\mathrm{r}_{\mathrm{p}}$ \\
\hline DU-hTP & 0.78 & 0.61 \\
DU-ITP & 0.55 & 0.85 \\
\hline
\end{tabular}

Furthermore, the level of glucose, triglycerides, creatinine and lactate were determined in the blood plasma (Fig. 4). The glucose concentration was about $10 \%$ higher in line DU-hTP (16.2 mmol/l) vs. line DU-ITP. This significantly increased level could be interpreted with a higher reaction of the organism for energy provision, which has to make available for the running performance in a short time.

The concentration of the triglycerides reacted in a contrary manner to the glucose. Whereas the mice of high treadmill performance line were tested with only 0.91 $\mathrm{mmol} / \mathrm{l}$ the low line DU-ITP were analysed with a significant higher level of triglycerides $(2.52 \mathrm{mmol} / \mathrm{l})$. Nearly the same ratio between the two mice lines were exposed for the trait creatinine in the blood plasma (DU-hTP: $78.5 \mathrm{mmol} / \mathrm{l}$, DU-lTP: $92.0 \mathrm{mmol} / \mathrm{l})$. However, the lactate concentration did not differ significantly between the long-term selected mouse lines.

\section{Discussion}

Because of the interactions between the genome and environmental factors a homeostasic metabolism stage will be adjusted to an animal. The direct or indirect selection on a special performance trait could influence this homeostasis and the animal has to adapt accordingly as be seen after selection it could be shown after longterm selection for growth in mice (FALKENBERG et al., 2000).

The training for endurance fitness may distinctly change the metabolism stage of probands. For example the training for endurance fitness at man results in increased aerobe capacity and induces structural and biochemical changes in the trained muscles (SALTIN and GOLLNICK, 1986). Moreover, distinct reductions of blood lactate measures, of ventilation activity, of oxygen intake and of heartbeat are linked with high training intensity (CASABURI et al., 1987). In this connection, the blood lactate level in human is considered as a direct or indirect marker of training intensity (HENRITZE et al., 1985; YOSHIDA et al., 1982). But it is also established that with increased training intensity the blood lactate level will decrease (CASABURI et al., 1987). The effect of endurance fitness on a higher growth hormone and insulin-likegrowth-factor level in the blood is known (VANHELDER et al., 1984; BANG et al., 1990). The growth of muscle tissues will promoted. It is to assume that among the effect of training a genetic component is responsible for the predisposition to endurance fitness.

In mouse lines, long-term selection on high or low treadmill performance yielded in a remarkable high direct selection response. The results of selection and mating of the best or most inactive mice for breeding the next generation prove the genetic determination of those fitness traits. Fitness traits could be influenced by breeding and selection. The estimation of heritability in high treadmill performance came to 0.32 at 
the beginning of selection (RENNE et al., 1989). A genetic predisposition to locomotoric endurance fitness can also be expected in farm animals.

The selection experiment with mice also responded in indirect traits. The fertility performance measured as litter size at birth did not change in the line with high endurance fitness (DU-hTP) but increased significantly in line DU-lTP during the selection process (generation 1: 11.5 pubs/litter; generation 54: 14.2 pubs/litter). The pregnancy rate was unchanged. Body weight at day 42 as a growth trait likewise developed divergent in the two selected lines. Male mice in line DU-1TP became heavier (36.9 g; $121.5 \%$ ) whereas the adult males in line DU-hTP with high locomotory activity were somewhat smaller (29.9 g; $95.8 \%)$ compared to the start point (RENNE et al., 1989).

In endurance fitness trained female rats CHATTERON et al. (1995) found a longer dioestrus period and reduced hormone concentration. The results in the mouse experiment are not directly connected with that effects, because nothing but male mice were tested and selected for their endurance fitness by running only one time without training. The changes in the direct and indirect fitness traits are the reaction to the selection process.

Selection for high or low endurance fitness has influenced the tested biochemical traits in the blood plasma. The higher enzyme activities in the line DU-hTP indicate an increased and strained metabolism in those animals. Increased enzyme concentrations in the blood plasma of animals in the line DU-hTP demonstrate a high stress situation (ASAT, CK, LDH), potential permeability disturbances of cell membranes (ASAT) and organic injures (ASAT, ALAT, GGTP, AP) which is derived from several investigations of LENGERKEN and ALBRECHT (1977), KELLER and KRAFT (1988), LÖFFLER et al. (1990) as well as FALKENBERG and LANGHAMMER (1994). Despite of that ROGA-FRANK et al. (1997) found, that rats which were forced to run on the moving belt until their physical exhaustion had lower glucose concentrations in blood than control animals.

Mice with high endurance fitness are remarkable for their differed structural composition of cholesterol subgroups. While few running mice in line DU-ITP have a higher level of LDL+VLDL-cholesterol, the proportion of HDL-cholesterol is excessively enriched in the blood plasma of much running mice (DU-hTP). The changed cholesterol composition can be assumed as a indirect result of selection for high running performance. The DU-hTP mice are the entirely mice which are characterised with such a high HDL-cholesterol percentage.

The power supply system in the energy metabolism has distinctly changed. The blood plasma traits show a better ability to a rapid energy provision with glucose in animals of the high performance line. Against that, in the low line the triglyceride provision will play a more important role. The small differences in the lactate concentration may be a result of a rapidly decreased blood lactate level after strong treadmill performance stress (CASABURI et al., 1994).

Long-term selection for high or low treadmill performance as a character for endurance fitness succeeded in significant differences in direct and indirect selection traits. In laboratory animals we found considerably changes in physical and biochemical traits between the selected lines. The results can make a contribution to 
estimation of fitness and stress susceptibility in animals.

\section{References}

BANG, P.; BRANDT, J.; DEGERBLAD, M.:

Exercise-induced changes in insulin-like growth factors and their low molecular weight binding protein in healthy subjects and patients with growth hormone deficiency. Eur. J. Clin. Invest. 20 (1990), 285292

CASABURI, R.; STORER, T. W.; SULLIVAN, C. S.; WASSERMAN, K.:

Evaluation of blood lactate elevation as an intensity criterion for exercise training. Med. Sci. Sports Exerc. 27 (1994), 852-862

CASABURI, R.; STORER, T.W.; WASSERMAN, K.:

Mediation of reduced ventilatory response to exercise after endurance training. J. Appl. Physiol. 63 (1987), 1533-1538

CHATTERON, R. T., jr.; HRYCYK, L.; HICKSON, R. C.:

Effect of endurance exercise on ovulation in the rat. Med. Sci. Sports Exerc. 27 (1995), 1509-1515

FALKENBERG, $H$.; LANGHAMMER, $M$.:

Vergleich des Creatinkinase-(CK-)gehaltes im Blut mit Merkmalen der Mast- und Schlachtleistung beim Schwein. Arch. Tierz., Dummerstorf 37 (1994), 611-622

FALKENBERG, H.; RENNE, U.; LANGHAMMER, M.:

Biochemical characterisation of blood metabolic substances in mice after long-term selection on growth traits. Arch. Tierz., Dummerstorf 43 (2000), 375-385

FLACHOWSKY, G.:

Einflußmöglichkeiten der Tierernährung auf Inhaltsstoffe und Qualităt von Tierprodukten. Wiss. Tag., Lohmann-LTE-GmbH, Mai 1996, Cuxhaven, Proc. 81-103

HENRITZE, J.; WELTMAN, A.; SCHURRER, R. L.; BARLOW, K.:

Effects of training at and above the lactate threshold on the lactate threshold and maximal oxygen uptake. Eur. J. Appl. Physiol. 54 (1985), 84-88

KELLER, P.; KRAFT, W.:

Einsatz der klinischen Chemie als Hilfsmittel zur Diagnose von Erkrankungen kleiner Haustiere. Tierärztl. Praxis 16 (1988), 307-315

LENGERKEN, G., v.; ALBRECHT, V.:

Eignung biochemischer Kennwerte und ausgewăhlter Regulationssysteme fur die Fruherkennung einer Prädisposition zur Ausbildung von Fleischqualitătsmängeln beim Schwein. Univ. Leipzig, Habilschrift 1977

LÖFFLER, G.; PETRIDES, E.; WEISS, L.: Physiologische Chemie. Springer-Verlag, Berlin, 1990

RENNE, U.; BÜNGER, L.; HERRENDÖRFER, G.: Results of long-term selection for stress-resistance traits-model analysis with laboratory mice. 7. Leipziger Tierzuchtsymposium, 12.-13. Dezember 1989, Proc., 118-129

RENNE, U.; BÜNGER, L.; SCHÜLER, L.: Experimentelle Untersuchungen an Labormäusen zur Selektion auf Belastbarkeit Belastbarkeitskonzept und Versuchsdurchfuhrung. Arch. Tierz., Berlin 27 (1984), 453-463

RENNE, U.; SUMPF, D.; HERRENDÖRFER, G.: Endurance fitness in a complete diallel cross among long-term selected mouse lines. Arch. Tierz., Dummerstorf 40 (1997), 483-490

ROGA-FRANC, M.; KOSLA, T.; ROKICKI, E.:

Haematological and biochemical indices of blood serum in rats forced to training. 9th Int. Congr.Animal Hygiene, 17.-21. August, 1997, Helsinki, Proc., Vol. 2: 933-936

SALTIN, B.; GOLLNICK, P. D.:, Skeletal muscle adaptability: Significance for metabolism and performance. In: Handbook of Physiology: Skeletal Muscle. Washington, DC: American Physiol. Soc. 1986, 555-631

SCHÜLER, L.:

Der Măuseauszuchtstamm FZT-DU und seine Anwendung als Modell in der Tierzuchtforschung. Arch. Tierz., Berlin 28 (1985), 357-363 
VANHELDER, W.; GOODE, R.C.; RADOMSKI, M. W.:

Effect of anaerobic and aerobic exercise of equal duration and work expenditure on plasma growth hormon levels. Eur. J. Appl. Pysiol. 52 (1984), 255-257

YOSHIDA, T.; SUDA, Y.; TAKEUCHI, N.:

Endurance training regimen based upon arterial blood lac ate: Effects on anaerobic threshold. Eur. J. Appl. Physiol. 49 (1982), 223-230

Received: 2000-05-19

Accepted: 2000-08-31

\author{
Authors' addresses \\ Dr. habil. HEINZ FALKENBERG \\ Institute for Applied Agroecology Rostock \\ Justus-von-Liebig-Weg 8 \\ D-18059 Rostock \\ Germany
}

Dr. MARTINA LANGHAMMER, Dr. ULLA RENNE

Research Institute for Biology of Farm Animals

Division of Population Biology and Breeding Research

Wilhelm-Stahl-Allee 2

D-18196 Dummerstorf

Germany

E-Mail: langham@fbn-dummerstorf.de 